\title{
Promotion mix practices of market leaders: a cross- sector analysis
}

\author{
R. Abratt, N. Chorn and B.I.C. van der Westhuizen \\ Graduate School of Business Administration, University of the Witwatersrand, Johannesburg
}

\begin{abstract}
Models which describe promotions practice in various situations have tended to be widely accepted without much attempt at empirical validation. Many approaches rely on the popular dichotomy which separates 'consumer' and 'industrial' marketing. It is argued that this separation is not entirely justified as far as the promotional activities of advertising and selling are concerned, and that the traditional models do not adequately describe promotions strategy in South African companies. The objective of this article is to review some of these approaches and to compare them with current findings of leading South African companies. A study of 25 leading companies across five sectors was undertaken. The purpose was to evaluate their promotions mix practices, and specifically to compare levels of expenditure on advertising and personal selling. The results are somewhat surprising, showing that personal selling expenditure is greater than advertising in all five the sectors studied.
\end{abstract}

S. Afr. J. Bus. Mgmt. 1986, 17: $24-30$

Modelle wat die verskillende promosiepraktyke beskryf, is gewoonlik aanvaar sonder dat daar gepoog is om dit empiries te bekragtig. Baie van die benaderings berus op verdeling in 'verbruiker'- en 'industriële' bemarking. Daar word aangevoer dat hierdie skeiding nie heeltemal geregverdig is sover dit promosie-aktiwiteite t.o.v. advertensies en verkope aangaan nie, en dat die tradisionele modelle die promosiestrategie in Suid-Afrikaanse firmas nie voldoende beskryf nie. Die doel van hierdie artikel is om 'n oorsig van sommige van die benaderings te gee en hulle te vergelyk met die bevindinge van toonaangewende Suid-Afrikaanse firmas. Vyf-en-twintig vooraanstaande firmas uit vyf sektore is ondersoek. Die doel was om hulle promosiepraktyke te evalueer, en meer spesifiek, om hulle uitgawes op advertensies en verkope te vergelyk. Die resultate is ietwat verbasend deurdat dit toon dat in al vyf sektore die uitgawes t.o.v. verkope meer is as die uitgawes t.o.v. advertensies.

S.-Afr. Tydskr. Bedryfsl. 1986, 17: $24-30$

R. Abratt*, N. Chom and B.I.C. van der Westhuizen Graduate School of Business Administration, University of the Witwatersrand, Johannesburg, P.O. Box 31170, Braamfontein, 2017 Republic of South Africa

*To whom correspondence should be addressed

\section{Introduction}

Approaches to promotions practice

Surprisingly little has been published during the past few years on the promotions practices of companies. In general, the 'standard' models which describe the promotions practice in various situations have tended to be widely accepted without much attempt in recent times at empirical validation. The objective of this article is to review some of these approaches and to compare them with current findings of leading South African companies.

Many of these approaches rely on the popular dichotomy which separates 'consumer' and 'industrial' marketing. It is argued that this separation is not entirely justified as far as the promotional activities of advertising and selling are concerned, and that the traditional models do not adequately describe promotions strategy in South African companies.

The promotions strategy in an organization is viewed as an implement for exploiting market opportunities. It has a catalytic function in the marketing strategy, and is used mainly to shift demand and expedite the buyer's decision process. In general, this involves altering the pattern of buyer behaviour so that the total demand schedule facing the company in question is increased (Hirschleifer, 1976). In reality, this usually also involves a reallocation of the total demand in favour of the promoting company.

There is broad agreement about the various influence processes that constitute the so-called promotions mix. (Luck \& Ferrell, 1985; Pride \& Ferrell, 1985; McCarthy \& Perreault, 1984; Stanton, 1984; Kotler, 1984; Schewe \& Smith, 1980.) These elements are advertising, personal selling, publicity and sales promotion, and the marketer is expected to combine all or some of these in varying degrees to achieve overall marketing objectives. The extent to which these different influence processes are used in the promotions mix is the subject of this article. In particular, the use of advertising and personal selling will be focused upon, because these elements usually receive major allocations in the overall promotions budget.

The promotions mix

The constitution of the promotions mix is usually seen as being contingent upon a number of factors, both within the marketing environment and the organization itself. These factors may be grouped into six general categories, and relate to the nature of the product being marketed, the nature of the market, the stage of the product life cycle, the degree of buyer-readiness, the resources available to the organization and the overall marketing policies and objectives of the company. (Pride \& Ferrell, 1985; McCarthy \& Perreault, 1984; Stanton, 1984; 
Kotler, 1984; Engel, Warshaw \& Kinnear, 1983; Schewe \& Smith, 1980.)

An analysis of the factors within the categories above reveals a common thread which runs through many of them. This relates to the distinction that is often made between 'consumer' and industrial' marketing. This dichotomy appears to be a significant variable in determining the constitution of the promotions mix, and in particular, the relative importance of the advertising and personal selling elements. Figures 1 and 2, which show the models of Kotler and McCarthy respectively, serve to illustrate this point.

Both models emphasize the importance of the distinction between consumer and industrial marketing in deciding on the relative emphasis between advertising and personal selling in the promotions mix. In doing so, they attempt to summarize many of the factors in the six general categories described above.

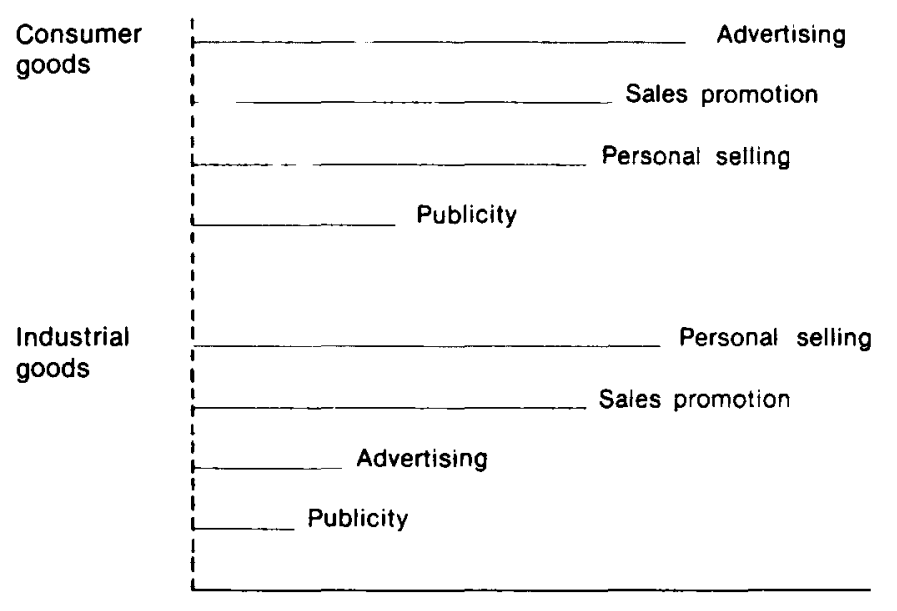

Relative importance

Figure 1 Relative importance of promotional tools in consumer vs industrial marketing (from Kotler, 1984).

\begin{tabular}{|c|c|c|c|}
\hline $10: 1$ & $\begin{array}{c}5: 1 \\
\text { Advertising } \\
\text { emphasis }\end{array}$ & $1: 1$ & $\begin{array}{c}1: 5 \\
\text { Personal } \\
\text { selling emphasis }\end{array}$ \\
\hline & $\begin{array}{l}\text { Firms with well } \\
\text { branded consumer } \\
\text { goods }\end{array}$ & & $\begin{array}{l}\text { Smaller companies and } \\
\text { anyone offering } \\
\text { relatively undifferentiated } \\
\text { consumer goods or } \\
\text { industrial goods }\end{array}$ \\
\hline
\end{tabular}

Figure 2 Relative importance of advertising and personal selling in consumer and industrial marketing (from McCarthy \& Perreault, 1984).

\section{Consumer vs industrial marketing}

The basis of the current dichotomy between consumer and industrial marketing appears to be an analysis of the major point of difference made by the Industrial Marketing Committee Review Board in 1954 (Industrial Marketing Committee Review Board, 1954). These differences are comprehensively listed by Fern \& Brown (1984) and are summarized under five categories: the nature of the product, the nature of the buying decision, characteristics of the buying decision, the nature of the seller's marketing activities, and the nature of the environmental influences. However, they point out that a number of counter-arguments exist on these differences, and that a good case can be made for viewing several aspects of consumer and industrial marketing from a single viewpoint.
For example, models of buyer behaviour have a great deal of similarity in their descriptions of industrial and consumer buying patterns. (Sheth, 1974; Zaltman \& Wallendorf, 1979; Webster \& Wind, 1972). Wind (1978) also spoke of the similarities that exist between segmentation approaches in consumer marketing, and those applicable to industrial marketing. Furthermore, the classification of 'consumer' and 'industrial' marketing is put to an ultimate test by testing the effectiveness of the classification scheme. (Fern \& Brown, 1984.) It is concluded that this dichotomy falls short on a number of points:

- There is no general agreement as to which phenomena should be used in the classification, or to their adequacy in providing a meaningf $\mu$ l classification.

- The classification is not mutually exclusive, i.e. a number of products, markets, purchase situations, and activities may be classified under either 'consumer' or 'industrial'.

- The classification does not produce categories which are collectively exhaustive, i.e. the classification of services marketing, social marketing and international marketing are not adequately provided for.

- The classification is not particularly useful. It purports to allow the development of different marketing strategies for different segments. However, due to the great number of similarities that exist, these may be more useful for the formulation of strategy than the differences.

Consequently, it may be said that the strict classification of producers, markets and buyer behaviour into 'consumer' or 'industrial' marketing has limited significance for the formulation of marketing strategy. It follows, therefore, that the constitution of the promotions mix will not necessarily benefit either from this classification.

\section{Concentration of buyer power}

One of the more significant structural changes that has occurred in the South African economy over the past number of years has been the increasing concentration of more areas of economic activity into the hands of a few large companies (Human, 1984). Human (1984) quoted figures which at the time suggested that some $80 \%$ of the gross assets of companies listed on the JSE were owned by 12 groups, and that $3,5 \%$ of manufacturers employed some 50570 of the employees. This concentration of economic and market power has been increasing as a result of mergers and acquisitions. One of the inevitable consequences of this is the increasing concentration of buyer power in the various markets of South Africa. Nielsen S.A. (1985) reported that in 1983 some $58,8 \%$ of the food and grocery trade was controlled by only $2,2 \%$ of the total stores. If one recognizes that most of these stores belong to one of a few large chains, the concentration of buyer power becomes even greater.

Porter (1980) pointed out that powerful buyer groups can exert strong bargaining power over suppliers, often at the expense of industry profits. In these cases, the supplier is advised to select his markets so that the balance of power between supplier and buyer becomes more favourable for the supplier. However, this is not always possible, and the marketing company will have to formulate strategies to account for the structural characteristics of the market. One of these strategies has been the development of the position of National Accounts Manager, whose primary concern is to serve the needs of powerful customers on whom the marketing company is disproportionately dependent (Bragg, 1982). This involves the creation of additional positions in the area of personal selling, and the marketing company often reallocates its pro- 
motional expenditure away from media advertising to support this. From a marketing strategy point of view, this means trading off strategies which add value to the product offering (e.g. branding, advertising, warranties) in favour of those that add value to the customer (e.g. account management). Brand and product management structures, which focus attention on the continued development and improvement of the company's product offering, will give way to structures designed to enhance the responsiveness and sensitivity of the marketing company to the customer's needs. This adjustment is inevitable in highly competitive markets, but marketers should be aware of the change in strategic emphasis in their businesses.

In order to determine the impact that this concentration of buyer power has on the promotions activities of marketing companies, a study of 25 leading companies across five sectors was undertaken. The purpose was to evaluate their promotions mix practices, and specifically to compare levels of expenditure on advertising and personal selling. To this end, an analysis of expenditure on promotional activities was undertaken and compared with a similar study done in four different national markets. In addition, a number of factors concerning the responsibility for and organization of the promotional effort were analyzed to gain some insight into how leading companies are coping with promotional activities in competitive markets.

\section{Methodology}

A sample of 25 companies was chosen, with the following distribution:

- Five manufacturers of fast-moving, non-durable consumer goods (food and allied products).

- Five manufacturers of durable consumer goods (furniture, appliances and motor vehicles).

- Five in the services sector (banking, financial institutions and car hire).

- Five in the industrial goods sector (raw materials and components).

- Five in the capital goods sector (heavy plant and equipment).

In selecting the firms in the above categories, a representative cross-section of industry leaders was selected because it was assumed that their expenditure and management of the promotion mix would in theory reflect a certain efficiency, and could therefore perhaps be used as a model for other firms in a particular industry.

The authors defined industry leaders as either the highest market share holders and/or the highest profile firms in that particular industry.

A very accurate description of this sample is not possible because it will easily identify these companies. However, the following information is pertinent. All the firms operate throughout Southern Africa. Seventeen companies are quoted in the Johannesburg Stock Exchange and eight are private companies. Ten of the firms were in the top 100 companies, as listed by the Financial Mail's Top Company Survey in May 1984. Eleven of the firms had a pre-tax profit of R2,5 milion or more and 14 had a pre-tax profit of between RI million and R2,5 million. The authors are of the opinion that this sample is representative of industry leaders. However, it cannot be statistically tested and therefore is an acknowledged limitation of this study.

An interview schedule was developed and pre-tested on two firms in each sector. It was found to be satisfactory. All respondents were interviewed by personal interview during the latter half of 1984 and January/February 1985. The results are presented below.

\section{Results}

\section{Promotion mix expenditures}

The promotion mix expenditures expressed as a percentage of sales are presented in Table 1.

The fast-moving consumer goods respondents spent the most on promotion. They spent $11,5 \%$ of turnover on promotion. It is interesting to note that their personal selling expenditure was $4,3 \%$ of turnover whereas advertising expenditure was only $3,2 \%$ of sales. This finding is unexpected and contrary to popular belief. The services sector spent $7,2 \%$ of sales on promotion, the durables sector $4,7 \%$, industrial goods 4,4 and capital goods $4,2 \%$

In all five sectors personal selling expenditure expressed as a percentage of sales was greater than advertising expenditure. Although this is not surprising in the capital goods, industrial goods and services sectors, it is surprising in the fast-moving consumer goods and consumer durables sectors.

In 1984, Zif, Young \& Fenwick presented an empirical analysis of advertising expenditures in different national markets. Their sample consisted of 2012 firms; 1732 in the United States, 157 in the United Kingdom, 105 in Canada, and 102 in Europe. They also divided their sample into consumer and industrial companies. They found that consumer companies spent $11,8 \%$ of turnover on promotion in the United States; $14,6 \%$ in the United Kingdom; $12,7 \%$ in Canada and $23,0 \%$ in Europe. Industrial companies spent $8,1 \%$ in the United States; 7,0\% in the United Kingdom; $12,7 \%$ in $\mathrm{Ca}$ nada; and $10,1 \%$ in Europe. In all the countries surveyed, industrial companies spend more as a percentage of sales on selling than on advertising.

Table 1 Promotion mix expenditures (\% of Sales)

\begin{tabular}{lccccc}
\hline & \multicolumn{5}{c}{ Industry sector } \\
\cline { 2 - 6 } $\begin{array}{l}\text { Type of } \\
\text { promotion }\end{array}$ & FMCG & Durables & Services & $\begin{array}{c}\text { Capital } \\
\text { Goods }\end{array}$ & $\begin{array}{c}\text { Indust. } \\
\text { Goods }\end{array}$ \\
\hline $\begin{array}{l}\text { Advertising } \\
\text { Sales } \\
\quad \text { Promotion }\end{array}$ & 3,24 & 1,41 & 0,85 & 0,44 & 0,29 \\
$\begin{array}{l}\text { Public } \\
\text { Relations }\end{array}$ & 0,75 & 0,86 & 0,92 & 0,49 & 0,17 \\
$\begin{array}{l}\text { Personal } \\
\quad \text { Selling }\end{array}$ & 4,27 & 0,13 & 0,26 & 0,12 & 0,12 \\
Total & 11,49 & 4,72 & 7,20 & 4,18 & 4,38 \\
\hline
\end{tabular}

\section{Responsibility for budget determination}

The responsibility for the determination of the budget for the various elements of the promotion mix is shown in Table 2.

There was a relatively high percentage of board and top management involvement in determining the advertising budget. On the other hand the executive committee was relatively less involved. It was surprising that only in the fastmoving consumer goods sector and the services sector were the marketing directors/managers responsible for determining the advertising budget. Other people that were involved in the advertising budget were mainly advertising managers or product managers.

There was less involvement by the board of directors in determining the sales promotion budget when compared to the advertising budget. Top management was relatively more involved, particularly in the industrial goods sector. There was very little involvement by the executive committee in determining the sales promotion budget. The highest involvement was 
Table 2 Responsibility for budget determination

\begin{tabular}{|c|c|c|c|c|c|c|c|c|c|c|}
\hline & \multicolumn{10}{|c|}{ Industry sector } \\
\hline & \multicolumn{2}{|c|}{ FMCG } & \multicolumn{2}{|c|}{ Durables } & \multicolumn{2}{|c|}{ Services } & \multicolumn{2}{|c|}{$\begin{array}{l}\text { Capital } \\
\text { Goods }\end{array}$} & \multicolumn{2}{|c|}{$\begin{array}{l}\text { Indust. } \\
\text { Goods }\end{array}$} \\
\hline & No. & $\%$ & No. & $\%$ & No. & $\%$ & No. & $\%$ & No. & $\%$ \\
\hline \multicolumn{11}{|l|}{ Advertising } \\
\hline $\begin{array}{l}\text { Board of Dir. } \\
\text { Top }\end{array}$ & 1 & 20 & 2 & 40 & 2 & 40 & 2 & 40 & 2 & 40 \\
\hline Management & 2 & 40 & 2 & 40 & 3 & 60 & 1 & 20 & 3 & 60 \\
\hline $\begin{array}{l}\text { Executive Com. } \\
\text { Marketing }\end{array}$ & 1 & 20 & 1 & 20 & - & - & 2 & 40 & 1 & 20 \\
\hline Director/Man. & 5 & 100 & 2 & 40 & 5 & 100 & 3 & 60 & 1 & 20 \\
\hline Other & 2 & 40 & 1 & 20 & - & - & 1 & 20 & 1 & 20 \\
\hline \multicolumn{11}{|l|}{ Sales promotion } \\
\hline $\begin{array}{l}\text { Board of Dir. } \\
\text { Top }\end{array}$ & 1 & 20 & 1 & 20 & 2 & 40 & 2 & 40 & 2 & 40 \\
\hline Management & 2 & 40 & 2 & 40 & 2 & 40 & 1 & 20 & 3 & 60 \\
\hline $\begin{array}{l}\text { Executive Com. } \\
\text { Marketing }\end{array}$ & 1 & 20 & - & - & - & - & 2 & 40 & 1 & 20 \\
\hline Director/Man. & 5 & 100 & 4 & 80 & 4 & 80 & 3 & 60 & 1 & 20 \\
\hline Other & 2 & 40 & 2 & 40 & 1 & 20 & 1 & 20 & 1 & 20 \\
\hline \multicolumn{11}{|l|}{ Public relations } \\
\hline $\begin{array}{l}\text { Board of Dir. } \\
\text { Top }\end{array}$ & - & - & 1 & 20 & 2 & 40 & 2 & 40 & 2 & 40 \\
\hline Management & 2 & 40 & 2 & 40 & 3 & 60 & 1 & 20 & 3 & 60 \\
\hline $\begin{array}{l}\text { Executive Com. } \\
\text { Marketing }\end{array}$ & 1 & 20 & - & - & - & - & 2 & 40 & 1 & 20 \\
\hline Director/Man. & 4 & 80 & 3 & 60 & 4 & 80 & 3 & 60 & 1 & 20 \\
\hline Other & 2 & 40 & 3 & 60 & - & - & 1 & 20 & 1 & 20 \\
\hline \multicolumn{11}{|l|}{ Sales force } \\
\hline $\begin{array}{l}\text { Board of Dir. } \\
\text { Top }\end{array}$ & - & - & 1 & 20 & - & - & - & - & 2 & 40 \\
\hline Management & 1 & 20 & 1 & 20 & 1 & 20 & 2 & 40 & 2 & 40 \\
\hline $\begin{array}{l}\text { Executive Com. } \\
\text { Marketing }\end{array}$ & 1 & 20 & - & - & - & - & - & - & 1 & 20 \\
\hline $\begin{array}{l}\text { Director/Man. } \\
\text { Sales Director/ }\end{array}$ & 3 & 60 & 2 & 40 & 3 & 60 & 3 & 60 & 1 & 20 \\
\hline Manager & 3 & 60 & 4 & 80 & 2 & 40 & 3 & 60 & 1 & 20 \\
\hline Other & 1 & 20 & - & - & 1 & 20 & 1 & 20 & 1 & 20 \\
\hline
\end{tabular}

by the marketing directors/managers in all but the industrial goods sector. A reasonably high percentage of other involvement was reported, this being mainly general managers and advertising managers.

The board of directors was generally speaking not involved in determining the public relations budget. There was even less involvement from the executive committee. Marketing directors/managers were substantially involved except in the industrial goods sector.

The board of directors and top management were only involved in the sales force budget in a few companies. The executive committee was hardly involved at all. The highest involvement in the sales force budget were the sales directors/ managers who accounted for just over half of the firms surveyed. Under half of the respondents reported that the marketing director/manager was involved in the sales force budget. Regional managers and product managers were also involved in some firms.

\section{Methods used to set the advertising budget}

The methods used to set the advertising budget are presented in Table 3.

The percentage of sales and objective and task methods were used by firms in all five of the market sectors. The use of these two methods was higher in the fast-moving consumer goods and consumer durables sectors and tapered off toward
Table 3 Methods used to set the advertising budget

\begin{tabular}{|c|c|c|c|c|c|c|c|c|c|c|}
\hline \multirow[b]{3}{*}{ Method } & \multicolumn{10}{|c|}{ Industry sector } \\
\hline & \multicolumn{2}{|c|}{ FMCG } & \multicolumn{2}{|c|}{ Durables } & \multicolumn{2}{|c|}{ Services } & \multicolumn{2}{|c|}{$\begin{array}{l}\text { Capital } \\
\text { Goods }\end{array}$} & \multicolumn{2}{|c|}{$\begin{array}{l}\text { Indust. } \\
\text { Goods }\end{array}$} \\
\hline & No & $.0 \%$ & No. & $\%$ & No. & $\%$ & No. & $\%$ & No. & $\%$ \\
\hline $\begin{array}{l}\text { Affordable } \\
\text { method }\end{array}$ & 1 & 20 & - & - & - & - & 2 & 40 & 3 & 60 \\
\hline$\%$ of sales & 2 & 40 & 4 & 80 & 1 & 20 & 1 & 20 & 1 & 20 \\
\hline $\begin{array}{l}\text { Competitive } \\
\text { parity }\end{array}$ & 3 & 60 & 1 & 20 & - & - & - & - & - & - \\
\hline $\begin{array}{l}\text { Objective and } \\
\text { lask }\end{array}$ & 4 & 80 & 2 & 40 & 3 & 60 & 2 & 40 & 1 & 20 \\
\hline Other & - & - & - & - & 1 & 20 & 1 & 20 & - & - \\
\hline
\end{tabular}

the capital goods and industrial goods sectors.

The affordable method was the main method used in the industrial goods sector. Only the fast-moving consumer goods and consumer durables sectors used the competitive parity method. The objective and task method was used by the majority of the firms in the fast-moving consumer goods and service sectors. These findings tend to support the findings of the Patti \& Blasko study in 1981. Patti \& Blasko (1981) studied the methods of budgeting used by large United States advertisers. They surveyed the entire list of companies listed in Advertising Age's 100 leading advertisers in 1980. They found that $51 \%$ of the advertisers used quantitative methods and $63 \%$ used the objective and task approach. Only $20 \%$ of their respondents used the affordable method of budget setting. They stated that many advertising managers have begun adopting the more sophisticated budgeting techniques and have relied less on the judgemental approaches to budget determination.

\section{Promotion organization}

The firms with their own advertising and public relations departments are shown in Table 4 . It can be seen that $68 \%$ of the respondents did not have their own advertising department and that the spread was comparatively the same throughout all five the sectors.

Fifty-two per cent of the respondents did not have their own public relations department. There were no major differences amongst the five sectors studied.

It can be seen from Table 5 that almost all the firms used advertising agencies. Only $12 \%$ of the respondents did not use advertising agencies. For a good discussion of factors that

Table 4 Number of firms with own advertising and public relations departments

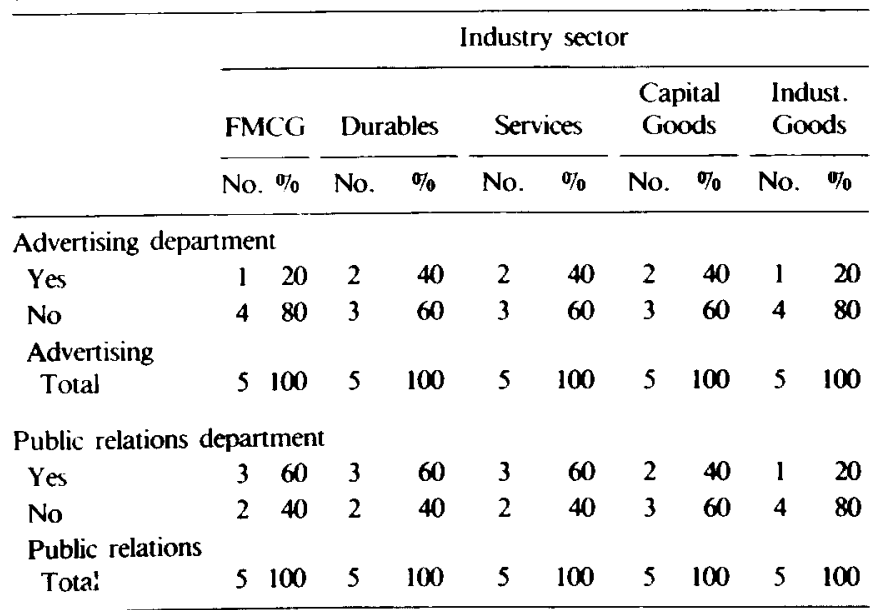


Table 5 Number of fims using advertising and public relations agency

\begin{tabular}{|c|c|c|c|c|c|c|c|c|c|}
\hline & \multicolumn{9}{|c|}{ Industry sector } \\
\hline & \multirow{2}{*}{$\frac{\text { FMCG }}{\text { No. } \%}$} & \multicolumn{2}{|c|}{ Durables } & \multicolumn{2}{|c|}{ Services } & \multicolumn{2}{|c|}{$\begin{array}{l}\text { Capital } \\
\text { Goods }\end{array}$} & \multicolumn{2}{|c|}{$\begin{array}{l}\text { Indust. } \\
\text { Goods }\end{array}$} \\
\hline & & No. & $\%$ & No. & $\%$ & No. & $\%$ & No. & $\%$ \\
\hline \multicolumn{10}{|c|}{ Advertising agency } \\
\hline Yes & 5100 & 4 & 80 & 5 & 100 & 4 & 80 & 4 & 80 \\
\hline No & $-\quad-$ & 1 & 20 & - & - & 1 & 20 & 1 & 20 \\
\hline Total & 5100 & 5 & 100 & 5 & 100 & 5 & 100 & 5 & 100 \\
\hline \multicolumn{10}{|c|}{ Public relations agency } \\
\hline Yes & 360 & 2 & 40 & 4 & 80 & 4 & 80 & 4 & 80 \\
\hline No & 240 & 3 & 60 & 1 & 20 & 1 & 20 & 1 & 20 \\
\hline Total & 5100 & 5 & 100 & 5 & 100 & 5 & 100 & 5 & 100 \\
\hline
\end{tabular}

advertisers use to assess the capabilities of prospective agencies, see the work by Cagley and Roberts, 1984. The objective of their study was to determine quantitative factors which advertisers use to assess the capabilities of current or prospective advertising agencies. A random sample of 125 firms was drawn from the firms listed in the 1984 Fortune 500 directory. They found that the attributes seen as most critical in the overall evaluation/selection process were the 'quality of people assigned to the account', followed by complete agreement between the agency and client on goals and objectives, and the 'need for agency personnel to thoroughly learn the characteristics of the advertisers business'. These findings reveal that the most critical criteria deal primarily with a 'people orientation'.

Attributes that were seen as least important in the evaluation process were the 'ability of the agency to handle all marketing research for the client', and the 'size, range, and balance of the agency's accounts' (Cagley \& Roberts, 1984).

Sixty per cent of the firms in the sample used a public relations agency. This indicates that some firms have their own public relations department as well as use an outside agency.

The persons ultimately responsible for advertising and public relations is presented in Table 6 .

When asked to state the title of the person ultimately responsible for advertising, it was interesting to observe that only in the fast-moving consumer goods and services sectors was there a $1: 1$ correlation with the person responsible for determining the advertising budget. It is difficult to understand why in the other three sectors more marketing directors/ managers were ultimately responsible for advertising, but did not participate in determining the budget. However, it is probably a case of the marketing director/manager being seen to be the person to be responsible for the advertising, irrespective of how the budget was set.

The majority of firms named the managing director as the person ultimately responsible for public relations, with the marketing director/manager some way back in second place. A small number of respondents mentioned the manufacturing director, the financial director and the public affairs manager.

Advertising media and sales promotion methods in use The advertising media used by the respondents are shown in Table 7. In examiring the media used, an interesting pattern developed.

Trade Press came out at the equal highest usage with $84 \%$ of respondents across the five sectors. It was particularly high in industrial goods where all of the firms used this media. Daily Press was very much lower with only $48 \%$ of the firms
Table 6 Title of person ultimately responsible for public relations and advertising

\begin{tabular}{|c|c|c|c|c|c|c|c|c|c|c|}
\hline & \multicolumn{10}{|c|}{ Industry sector } \\
\hline & \multicolumn{2}{|c|}{ FMCG } & \multicolumn{2}{|c|}{ Durables } & \multicolumn{2}{|c|}{ Services } & \multicolumn{2}{|c|}{$\begin{array}{l}\text { Capital } \\
\text { Groods }\end{array}$} & \multicolumn{2}{|c|}{$\begin{array}{l}\text { Indust. } \\
\text { Goods }\end{array}$} \\
\hline & No. & $\%$ & No. & $\%$ & No. & $\%$ & No. & $\%$ & No. & $\%$ \\
\hline \multicolumn{11}{|l|}{ Advertising } \\
\hline $\begin{array}{l}\text { Managing } \\
\text { Director }\end{array}$ & - & - & - & - & - & - & - & - & 2 & 40 \\
\hline $\begin{array}{c}\text { Marketing } \\
\text { Director/ }\end{array}$ & & & & & & & & & & \\
\hline Manager & 5 & 100 & 4 & 80 & 5 & $f(x)$ & 4 & 80 & 2 & 40 \\
\hline $\begin{array}{c}\text { Advertising } \\
\text { Manager }\end{array}$ & - & - & 1 & 20 & - & - & 1 & 20 & 1 & 20 \\
\hline \multicolumn{11}{|l|}{ Public relations } \\
\hline Director & 3 & 60 & 4 & 80 & 5 & 100 & 5 & 100 & 5 & 100 \\
\hline $\begin{array}{l}\text { Marketing } \\
\text { Director/ }\end{array}$ & & & & & & & & & & \\
\hline Manager & 1 & 20 & 2 & 40 & 3 & 60 & 2 & 40 & 1 & $\mathbf{2 0}$ \\
\hline $\begin{array}{l}\text { Public Affairs } \\
\text { Manager }\end{array}$ & 1 & 20 & 1 & 20 & - & - & - & - & - & - \\
\hline $\begin{array}{l}\text { Financial } \\
\text { Director }\end{array}$ & - & - & 1 & 30 & 1 & 20 & 1 & 20 & 1 & 20 \\
\hline $\begin{array}{l}\text { Manufacturing } \\
\text { Director }\end{array}$ & - & - & 1 & 20 & - & - & - & - & 1 & 20 \\
\hline
\end{tabular}

Table 7 Advertising media used

\begin{tabular}{|c|c|c|c|c|c|c|c|c|c|c|}
\hline \multirow[b]{3}{*}{ Medium } & \multicolumn{10}{|c|}{ Industry sector } \\
\hline & \multicolumn{2}{|c|}{ FMCG } & \multicolumn{2}{|c|}{ Durables } & \multicolumn{2}{|c|}{ Services } & \multicolumn{2}{|c|}{$\begin{array}{l}\text { Capital } \\
\text { Goods }\end{array}$} & \multicolumn{2}{|c|}{$\begin{array}{l}\text { Indust. } \\
\text { Goods }\end{array}$} \\
\hline & No. & & No. & $\%$ & No. & $\%$ & No. & $\%$ & No. & $\%$ \\
\hline Trade press & 4 & 80 & 4 & 80 & 4 & 80 & 4 & 80 & 5 & 100 \\
\hline Daily press & 3 & 60 & 4 & 80 & 2 & 40 & 3 & 60 & - & - \\
\hline Weekly press & 3 & 60 & 4 & 80 & 3 & 60 & 5 & 100 & - & - \\
\hline Radio & 5 & 100 & 4 & 80 & 3 & 60 & - & - & - & - \\
\hline Cinema & 2 & 40 & 1 & 20 & 2 & 40 & - & - & - & - \\
\hline Television & 5 & 100 & 4 & 80 & 3 & 60 & 1 & 20 & - & - \\
\hline Outdoor & $s$ & 100 & 3 & 60 & 3 & 60 & - & - & - & - \\
\hline Direct mail & 1 & 20 & 3 & 60 & 4 & 80 & 3 & 60 & 3 & 60 \\
\hline House mags & 1 & 20 & 2 & 40 & 4 & 80 & 4 & 80 & 4 & 80 \\
\hline Brochures & 2 & 40 & 5 & 100 & 5 & 100 & 5 & 100 & 4 & 80 \\
\hline Audio-visuals & 4 & 80 & 3 & 60 & 1 & 40 & 3 & 60 & 4 & 80 \\
\hline Other & 2 & 40 & 1 & 20 & - & - & - & - & - & - \\
\hline
\end{tabular}

and was predominantly used by fast-moving consumer goods and consumer durables, although capital goods also used Daily Press reasonably frequently. Weekly Press was also comparatively high, although only used by four of the five sectors and surprisingly was used by all of the capital goods sector firms.

Radio was only used by three of the sectors, understandably fast-moving consumer goods with all firms, consumer durables and services. Cinema was used by even less of the respondent firms - only $20 \%$ of the total - the highest recorded percentage being in fast-moving consumer goods with $40 \%$ of the firms. Television was used by just over half of the firms, although this was predominantly in the fast-moving consumer goods sector with all of the firms and consumer durables and services sector. Only one of the capital goods firms used television advertising.

Outdoor was again used predominantly by fast-moving consumer goods, consumer durables and service sectors and the highest recorded here was for fast-moving consumer goods 
with all of the firms.

Direct mail was used quite substantially by firms in the consumer durables, services, capital goods and industrial goods sectors. The total across the five groups being $56 \%$ of the firms.

House magazines were used by $80 \%$ of the firms in the services, capital goods and industrial goods sectors. Brochures and catalogues were used by all of the consumer durables firms, services sector firms and capital goods sector firms and by $80 \%$ of the industrial goods firms. Brochures and catalogues thus recorded an equal first as the highest media used.

The main forms of sales promotion used by the respondents are shown in Table 8.

Table 8 Main forms of sales promotion used

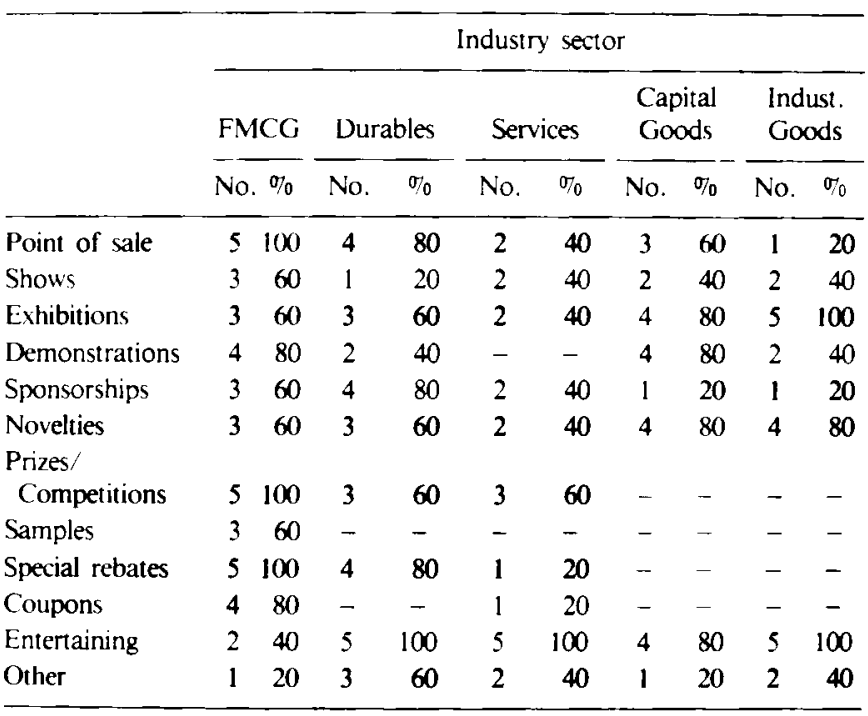

When enquiring about the main forms of sales promotion used it was interesting to note the high variations between the different sectors as well as within the individual sectors.

Point-of-sale material was understandably highest in the fast-moving consumer goods sector (with all of the firms using it) and consumer durables sector and less in industrial goods sector. There was a fairly high usage of shows, being mainly in the fast-moving consumer goods area. (It should be pointed out that shows were defined as being comparatively small events as compared with the exhibitions which were defined as being much larger scale operations.)

Substantial use was made of exhibitions with $68 \%$ of firms in total. Capital goods and industrial goods were the highest users of this form of promotion. Demonstrations were substantially used by fast-moving consumer goods (for example in-store promotions) and capital goods where the equipment was no doubt used in working conditions. Sports and other sponsorship were used mainly in the fast-moving consumer goods and consumer durables sectors. Novelties were used by $64 \%$ of all respondents but once again mainly in capital goods and industrial goods sectors. Prizes and competitions were used by all of the fast-moving consumer goods companies and also in the consumer durables and services sectors. Samples were only used by fast-moving consumer goods companies which is, of course, quite understandable.

Special rebates were also used by all of the fast-moving consumer goods companies as well as $80 \%$ of the consumer durables companies. Coupons were used by $80 \%$ of the fastmoving consumer goods sector firms and also by one of the firms in the services sector.
The highest recorded score for sales promotion used was for entertaining which scored $84 \%$ of all firms. However, all of the consumer durables, services and industrial goods companies reported using entertaining as a sales promotion method. Thirty-six per cent of the firms in all sectors reported using other forms of sales promotion and it was discovered that these consisted mainly of factory visits as well as conferences and conventions.

\section{Evaluation and Control}

Table 9 deals with the measurement of promotion effectiveness. Section (a) deals with advertising pre- and post-test research carried out by the respondents. Slightly more than half of the respondents claimed to do pre- and post-test research, mainly in the fast-moving consumer goods, consumer durables and services sectors. Section (b) deals with the measurement of public relations effectiveness. Only $20 \%$ of the firms claimed to have a formal measurement process for public relations effectiveness. The majority acknowledged that they only measured this effectiveness on an informal basis.

Section (c) deals with the measurement of sales promotion effectiveness. More than half of the firms referred to an informal method of measurement, whereas the balance claimed to have a formal method of measurement.

Section (d) shows how sales productivity is measured. Only one firm did not measure sales productivity by achievement of target. In other words $96 \%$ of the firms used the achievement of target as the main means of measurement of sales productivity.

Surprisingly, perhaps, is that only $40 \%$ of firms used profitability as a measure of sales productivity. The most prevalent in this case being firms in the capital goods sector. Sales competitions were used by $44 \%$ of firms which included all of those in the fast-moving consumer goods sector. Thirtytwo per cent of firms measured sales productivity by means

Table 9 Measurement of promotion effectiveness

\begin{tabular}{|c|c|c|c|c|c|c|c|c|c|c|}
\hline & \multicolumn{10}{|c|}{ Industry sector } \\
\hline & \multirow{2}{*}{\multicolumn{2}{|c|}{$\frac{\text { FMCG }}{\text { No. } \%}$}} & \multicolumn{2}{|c|}{ Durables } & \multicolumn{2}{|c|}{ Services } & \multicolumn{2}{|c|}{$\begin{array}{l}\text { Capital } \\
\text { Groods }\end{array}$} & \multicolumn{2}{|c|}{$\begin{array}{l}\text { Indust. } \\
\text { Goods }\end{array}$} \\
\hline & & & No. & $\%$ & No. & $\sigma_{0}$ & No. & $\mathbf{0 \%}$ & No. & $\%$ \\
\hline \multicolumn{11}{|c|}{ a) Advertising pre and post-test research carried out } \\
\hline Yes & 4 & 80 & 3 & 60 & 3 & 60 & 2 & 40 & 1 & 20 \\
\hline No & 1 & 20 & 2 & 40 & 2 & 40 & 3 & 60 & 4 & 80 \\
\hline Total & 5 & 100 & 5 & 100 & 5 & 100 & 5 & 100 & 5 & 100 \\
\hline \multicolumn{11}{|c|}{ b) Measurement of public relations effectiveness } \\
\hline Formal & 1 & 20 & 1 & 20 & 2 & 40 & - & - & 1 & 20 \\
\hline Informal & 4 & 80 & 3 & 60 & 3 & 60 & 4 & 80 & 3 & 60 \\
\hline None & - & - & 1 & 20 & - & - & 1 & 20 & 1 & 20 \\
\hline Total & 5 & 100 & 5 & 100 & 5 & 100 & 5 & 100 & 5 & 100 \\
\hline \multicolumn{11}{|c|}{ c) Measurement of sales promotion effectiveness } \\
\hline Formal & 4 & 80 & 3 & 60 & 3 & 60 & 2 & 40 & - & - \\
\hline Informal & 1 & 20 & 2 & 40 & 2 & 40 & 3 & 60 & 5 & 100 \\
\hline Total & 5 & 100 & 5 & 100 & 5 & 100 & 5 & 100 & 5 & 100 \\
\hline \multicolumn{11}{|c|}{ d) Measurement of sales productivity } \\
\hline Achieve target & 5 & 100 & 5 & 100 & 4 & 80 & 5 & 100 & 5 & 100 \\
\hline Profitability & 2 & 40 & 2 & 40 & 1 & 20 & 4 & 80 & 1 & 20 \\
\hline \multicolumn{11}{|l|}{ Sales } \\
\hline Competitions & 5 & 100 & 2 & 40 & 2 & 40 & 2 & 40 & - & - \\
\hline New Customers & 2 & 40 & 1 & 20 & 2 & 40 & 2 & 40 & 1 & 20 \\
\hline \multicolumn{11}{|l|}{ Market } \\
\hline Penetration & 3 & 60 & 3 & 60 & 3 & 60 & 4 & 80 & 3 & 60 \\
\hline \multicolumn{11}{|l|}{ Repeat } \\
\hline Business & - & - & 1 & 20 & 2 & 40 & 3 & 60 & 1 & 20 \\
\hline Other & - & - & 1 & 20 & 2 & 40 & - & - & - & - \\
\hline
\end{tabular}


of new customers gained. Market penetration was used by $64 \%$ of firms, being highest in the capital goods sector. Repeat business was used mainly by the firms in the capital goods sector, which is perhaps understandable because it is relatively easy to measure in this industry.

Methods of co-ordinating elements of the promotion mix are presented in Table 10 .

The majority $(68 \%)$, said this was done by the marketing plan with all of the capital goods sector firms claiming to do this. Next most important method was the firm's strategic plan which was used by $40 \%$ of the respondents. (It should be noted, however, that most of the firms who used these two methods actually used both. Curiously, although one would have thought that the co-ordination of the promotion elements would have been restricted to the marketing plan, they insisted that this was also covered in the strategic plan). The brand plan was used by $60 \%$ of the firms in the fast-moving consumer goods sector to co-ordinate their promotion mix elements. Only $8 \%$ used the business unit plan.

Four firms were honest enough to admit that they did not formally co-ordinate the promotion mix elements. Of these, three were in the industrial goods sector.

Table.10 Method of co-ordinating elements of the promotion mix

\begin{tabular}{|c|c|c|c|c|c|c|c|c|c|c|}
\hline & \multicolumn{10}{|c|}{ Industry sector } \\
\hline & \multicolumn{2}{|c|}{ FMCG } & \multicolumn{2}{|c|}{ Durables } & \multicolumn{2}{|c|}{ Services } & \multicolumn{2}{|c|}{$\begin{array}{l}\text { Capital } \\
\text { Goods }\end{array}$} & \multicolumn{2}{|c|}{$\begin{array}{l}\text { Indust. } \\
\text { Goods }\end{array}$} \\
\hline & No. & $\%$ & No. & $\%$ & No. & $\%$ & No. & $\%$ & No. & $\%$ \\
\hline Brand plan & 3 & 60 & - & - & - & - & - & - & - & - \\
\hline $\begin{array}{l}\text { Business } \\
\text { unit plan }\end{array}$ & 1 & 20 & 1 & 20 & - & - & - & - & - & - \\
\hline $\begin{array}{l}\text { Marketing } \\
\text { plan }\end{array}$ & 4 & 80 & 2 & 40 & 4 & 80 & 5 & 100 & 2 & 40 \\
\hline $\begin{array}{l}\text { Strategic } \\
\text { plan }\end{array}$ & 2 & 40 & 2 & 40 & 3 & 60 & 2 & 40 & 1 & 20 \\
\hline None & - & - & 1 & 20 & - & - & - & - & 3 & 60 \\
\hline
\end{tabular}

\section{Conclusions and Implications}

The study reports on the promotions practices of market leaders in five sectors of the market.

As might be expected, advertising expenditure, as a percentage of sales, is greatest in the fast-moving consumer goods sector and the smallest in the industrial goods sector. However, one of the major findings of the study is that personal selling expenditure is greater than advertising in all five the sectors studied. Particularly in the case of the durable and nondurable consumer goods companies, this would appear to be a result of the high concentration of buyer power in many sectors of the market. In many cases, this has resulted in increased emphasis for the account and sales management functions. In the case of these companies selling to wholesalers or retailers, it means that the middleman is receiving the bulk of the marketing company's promotional effort. Although this may be necessary in order to maintain channels of distri- bution to the final end user, it results in a reallocation of resources away from product development towards meeting the requirements of the middleman. Ultimately, this must reflect on the ability of these companies to meet the needs of the end user.

With the increased concentration of buyer power, marketing companies are finding that the nature of their marketing effort is changing, as the promotional mix analysis above indicates. This would tend to support the viewpoints of writers who suggest that the similarities rather than the differences between 'industrial' and 'consumer' marketing might be more meaningful for the formulation of appropriate marketing strategy (Fern \& Brown, 1984; Sheth, 1974; Zaltman \& Wallendorf, 1979; Wind, 1978; Webster \& Wind, 1972).

\section{References}

Bragg, A.J. 1982. National Account Managers to the Rescue. Sales Market. Mgmt., August, 30-34.

Cagley, J.W. \& Roberts, C.R. 1984. Criteria for Advertising Agency Selection: An Objective Appraisal. J. Adverlising Res. vol. $24,27-31$

Engel, J.F., Warshaw, M.R. \& Kinnear, T.C. 1983. Promotional Strategy: Managing the Marketing Communication Process. 5th Edition. Homewood, Illinois: Richard D Irwin.

Fern, E.F. \& Brown, J.R. 1984. The Industrial/Consumer Marketing Dichotomy: A Case of Insufficient Justification. $J$. Market., vol. 48, Spring, $68-77$.

Hirschleifer, J. 1976. Price Theory and Applications. Englewood Cliffs, N.J.: Prentice Hall.

Human, P. 1984. Bureaucracy and the need for entrepreneurship in South Africa. S. Afr. J. Bus. Mgmt., vol. 15(4), 212-219.

Industrial Marketing Committee Review Board. 1954. Fundamental Differences between Consumer and Industrial Marketing. $J$. Market. vol.19, October, $152-158$.

Kotler, P. 1984. Marketing Management: Analysis, Planning and Control. Sth Edition. Englewood Cliffs, N.J. Prentice-Hall.

Luck, D.J. \& Ferrell. O.C. 1985. Marketing Strategy and Plans. 2nd Edition, Englewood Cliffs, N.J.: Prentice-Hall.

McCarthy, E.J. \& Perreault, W.D. 1984. Basic Marketing. 8th Edition. Homewood, Illinois: Richard D Irwin.

Nielsen, A.C. and Company. Information supplied in an interview with company executives in 1985.

Patti, C.H. \& Blasko, V. 1981. Budgeting Practices of Big Advertisers. J. Advertising Res. vol 21, 23-29.

Pride, W.M. \& Ferrell, O.C. 1985. Marketing: Basic Concepts and Decisions, 2nd Edition. Boston: Houghton Mifflin.

Porter, M.E. 1980. Competitive Strategy: Techniques for Analysing Industries and Competitors. New York: The Free Press.

Stanton, W.J. 1984. Fundamentals of Marketing. 7th Edition. Tokyo: McGraw-Hill.

Schewe, C.D. \& Smith, R.M. 1980. Marketing: Concepts and Applications. Kogakusha: McGraw-Hill.

Sheth, J.N. 1974. A Theory of Family Buying Decisions, in Models of Buyer Behaviour. New York: Harper.

Webster, F.E. \& Wind, Y. 1972. Organisational Buying Behaviour. Englewood Cliffs, N.J.: Prentice-Hall.

Wind, Y. 1978. Issues and Advances in Segmentation Research. J. Market. Res., vol. 15, August, 317-337.

Zaltman, G. \& Wallendorf, M. 1979. Consumer Behaviour: Basic Findings and Management Implications. New York: Wiley.

Zif, J., Young, R.F. \& Fenwick, I. 1984. A Transnational Study of Advertising-to-Sales Ratios. J. Advertising Res. vol. 24, $58-63$. 